\title{
A New Spectacle in China's Mediasphere: A Cultural Reading of a Web-Based Reality Show from Shanghai*
}

Daria Berg ${ }^{\dagger}$

\begin{abstract}
This study offers a cultural reading of the web-based reality show Soul Partners (2007) from Shanghai. Soul Partners serves as a case study to explore how 21st-century Chinese cultural discourse debates the transformation of urban society in China, providing insight into the Chinese cultural imagination, perceptions of the globalizing metropolis and the impact of consumer culture. This reading positions Soul Partners within the discursive context of Chinese popular, postmodern and postsocialist culture and in relation to the cultural import of the reality show genre into China's mediasphere. Analysis focuses on the quest for authenticity in the Chinese discourse on perceived reality and the way Soul Partners generates new urban dreams for China's Generation X. The analysis of Soul Partners sheds new light on the dynamics of transcultural appropriation in a globalizing China and the social and political implications.
\end{abstract}

Reality shows have gained popularity in 21st-century China as part of a globalizing entertainment culture, providing the illusion of instant access to uncensored insights into lived experience. Such programmes appear to empower the audience by encouraging viewers to participate in the decision-making process. While Big Brother remains banned on national Chinese television, the launch of the webbased reality show (wangluo zhenrenxiu jiemu 网络真人秀节目) Soul Partners (Xinling paidang 心灵排挡) ${ }^{1}$ on the video-sharing website Mofile.com (mofangwang 魔方网) on 18 January 2007 demonstrates how webcasting enables a national audience to watch the protagonists enact "unscripted modernity" while establishing an interactive discourse between participants, producers and audience.

\footnotetext{
* I am grateful to Professors Glen Dudbridge, Guobin Yang, Yongnian Zheng, Qianlan Wu and the participants of the symposium "New information and communication technologies and transformation in China," University of Nottingham, June 2007, for invaluable comments, and the School of Contemporary Chinese Studies, University of Nottingham, for supporting this project.

† University of Nottingham. Email: daria.berg@nottingham.ac.uk

1 Produced by "lvlvlvlv dianying gongzuoshi" (lvlvlvlv film studio).
} 
Soul Partners created a storm in the media: following Chinese press reports, ${ }^{2}$ Reuters and CNN hailed the show as "Big Brother with Chinese characteristics," an indicator of the new "web freedoms" in China. ${ }^{3}$ Mofile in turn used the media discourse that described Soul Partners as "a frank reflection [of] Chinese popular opinion" to advertise its video-sharing platform on the Soul Partners website. ${ }^{4}$ Property developer Sanxiang Four Seasons Flower City (Sanxiang siji huacheng 三湘四季花城) Luxury Housing Company used it for product placement in return for sponsoring the setting, a luxury apartment in the newly constructed Thames Town (Taiwushi xiaozhen 泰晤士小鎮) suburb of Shanghai. ${ }^{5}$

Filmmakers have been collaborating with property developers since the mid-1990s, merging art, entertainment and commercial culture in China's rising "cultural economy" (wenhua jingji 文化经济), as Yomi Braester has shown. ${ }^{6}$ Product placement (literally "soft advertising" ruanxing guanggao 软性广告) or branded entertainment began in 1991 with the television drama Stories from an Editorial Office (Bianjibu de gushi 编辑部的故事) ${ }^{7}$ and appeared in Feng Xiaogang's 冯小刚 (1958-) blockbuster Cell Phone (Shouji 手机, 2003). ${ }^{8}$ Although advertisers pinpoint product placement as China's future marketing strategy, Jing Wang cautions that state control over media and market prevents its proliferation in China. ${ }^{9}$ Soul Partners exemplifies a new way of product placement by webcasting.

Our cultural reading of Soul Partners explores how the Chinese media debate the rapid transformation of life in China's cities, in particular Shanghai, the setting of Soul Partners and its site of production. Analysis of the show within its context enables new insights into the cultural imagination, perceptions of the globalizing metropolis, the impact of consumer culture and the dynamics of transcultural appropriation in China's mediasphere. Soul Partners is positioned within its cultural context including cinema, video art and the blogosphere.

This study adapts the concept of the mediasphere for the collective ecology of China's published and broadcast media as a framework for analysing cultural

2 Cf. Peijin Chen, "Friends - the Shanghai version," 24 January 2007, http://www.shanghaiist.com/ archives/2007/01/24/friendsthe_shan.php, accessed 7 September 2008.

3 Richard Spencer, "No Big Brother for Chinese viewers," Telegraph, 24 January 2007, http://www. telegraph.co.uk/news/main.jhtml?xml=/news/2007/01/23/wchina23.xml, accessed 1 May 2007; Sophie Taylor, "Chinese Friends highlights web freedoms," 6 February 2007, http://uk.news.yahoo.com/ 05022007/80-91/china-s-friends-highlights-web-freedoms.html, accessed 5 May 2007.

4 Mofile website, http://www.mofile.com/about/media.do, accessed 4 April 2007.

5 Soul Partners (Xinling paidang) website, http://actor.mofile.com/index/htm, accessed 2 June 2007 (no longer accessible as of September 2008).

6 Yomi Braester, "Chinese cinema in the age of advertisement: the filmmaker as a cultural broker," The China Quarterly, No. 183 (2005), pp. 549-64.

7 Michael Keane, "Television drama in China: engineering souls for the market," in Timothy J. Craig and Richard King (eds.), Global goes Local: Popular Culture in Asia (Honolulu: University of Hawai'i Press, 2002), pp. 120-37.

8 Cf. Zhenzhi Guo and Mei Wu, "Dancing thumbs: mobile telephony in contemporary China," in Xiaoling Zhang and Yongnian Zheng (eds.), China's Information and Communications Technology Revolution (London: Routledge, 2009), pp. 45-46.

9 Jing Wang, Brand New China: Advertising, Media, and Commercial Culture (Cambridge, MA: Harvard University Press, 2008), pp. 282-87. 
processes. The neologism "mediasphere" coined by Régis Debray denotes cultural production in the visual and textual fields characterized by endless expansion. ${ }^{10}$ These fields include novels, non-literary books, magazines, newspapers, advertisements, film, internet writings and the blogosphere. The mediasphere emphasizes the interconnectedness of these fields, transcending the boundaries between different texts, genres, media, high culture and popular culture. This concept provokes interest because it extends attention from "the visible system of the medium to the invisible macrosystem that gives it meaning." 11 I use Guy Debord's term "spectacle" as a commodity in analogy to Yu Huang's adaptation of the concept for the Chinese context, emphasizing the links between media, popular and commercial culture. ${ }^{12}$

Soul Partners deserves critical attention for two reasons: first, because cultural, political and commercial negotiations converge in its production and consumption, illustrating the transformation of China's new cultural discourse in post-Deng China; and second, because the show epitomizes new trends in contemporary Chinese popular culture. The discourse about Soul Partners highlights three specific aspects of contemporary popular culture in China: the impact of globalizing culture from Europe and the US on the quest for authenticity in postsocialist China; the consumer revolution entailing the rise of the advertising industry and a postmodern commercialized popular culture; and the digital revolution, specifically the rise of Web 2.0 technology providing a new interactive vehicle for cultural production and consumption that defies the party-state's censorship of China's mediasphere. ${ }^{13}$ Web 2.0 , a term coined in $1999,{ }^{14}$ denotes a new generation of web applications, including blogs, social networking and video-sharing sites emphasizing interactivity, information sharing and usercentred design. ${ }^{15}$ Blogging became popularized in China in 2003 following Muzi Mei's 木子美 weblog. From 2005 China experienced a growth in online video-sharing services with YouTube spin-offs including Mofile, Tudou 土豆 网, Youku 优酷 and 56.com. ${ }^{16}$

Soul Partners enjoyed a brief spell of stardom at the centre of the media hype. Mofile released the first seven episodes between January and March 2007. ${ }^{17}$ Nine instalments were planned for the first season, out of 20 in total. ${ }^{18}$ After the

10 Régis Debray, Cours de Médiologie Générale (Paris: Gallimard, 1991).

11 Alexander Des Forges, Mediasphere Shanghai (Honolulu: University of Hawai'i Press, 2007).

12 Yu Huang, "The Zhenrenxiu phenomenon in contemporary China," http://www.hope.ac.uk/docman/ cultures-in-transit-papers/yu-huang-the-zhenrenxiu-phenomenon-in-contemporary-china/details.html, accessed 6 October 2009, p. 12; Guy Debord, La Societé du Spectacle (Paris: Buchet/Chastel, 1967).

13 See Yongnian Zheng, Technological Empowerment (Stanford, CA: Stanford University Press, 2008).

14 Darcy DiNucci, "Fragmented future," Print, Vol. 53, No. 4 (1999), p. 32.

15 Tim O'Reilly, "What is Web 2.0," http://oreilly.com/web2/archive/what-is-web-20.html, accessed 5 November 2009.

16 Luyi Chen, "Tudou launches new website skin: seven services compared," China Web 2.0 Review, 25 November 2006, http://www.cwrblog.net/365/tudou-launches-new-website-skin-seven-servicescompared.html, accessed 14 November 2009.

17 Episodes varied in length between seven and 16 minutes.

18 Taylor, "Chinese Friends." 
seventh episode, however, the production stalled when the investor withdrew support. ${ }^{19}$ The ephemeral nature of the show typifies the new globalizing entertainment culture, revealing the dynamics of the new web-based discourse and exposing postmodern culture as a culture of rapid consumption. ${ }^{20}$

While the applicability of the postmodern condition to China has been the subject of debate, ${ }^{21}$ Xiaobing Yang defines postmodern in the Chinese context as resistance to the Mao-Deng discourse that "epitomizes the grand narrative of modernity, from which Chinese postmodernism defers and differs (in the Derridean sense)." 22 In cultural critique the postmodern refers to a "cultural paradigm that deconstructs the modern/Mao-Deng paradigm from within."23 Wang Ning identifies three manifestations of the postmodern in China: "as a post-structuralist theoretical discourse, as an avant-garde intellectual rebellion against the modernist episteme, and as a contemporary consumer culture," 24 the latter epitomized by best-selling novelist Wang Shuo 王朔 (1958-) and cultural commercialization. ${ }^{25}$

Here I position the reality show in relation to Chinese commercial culture as part of the post-Mao-Deng discourse and post-socialist modernity. ${ }^{26}$ Arif Dirlik first used the term post-socialism in 1989 to denote adjustments in socialist ideology in response to the vernacularization of socialism in different national contexts. ${ }^{27}$ I follow Dirlik and Chris Berry in defining the term by analogy to Jean-François Lyotard's notion of postmodernism, referring to a state "where the forms and structures of the modern (in this case socialism) persist long after faith in the grand narrative that authorizes it has been lost." 28 For our cultural reading, post-socialism denotes a "cultural logic" to "negotiate the residual socialist past and the emergent capitalist present to concoct new imaginaries of a transnational society," as Sheldon Lu notes. ${ }^{29}$

This study analyses, first, the cultural import of the reality show genre into China; second, the quest for authenticity in Chinese post-socialist discourse; third, the formation of new dreams for a new generation; fourth, audience

19 Personal email communication with Mofile CEO Jason Cai, 27 September 2008.

20 See also the online video "Bus uncle"; see Guo and Wu, "Thumbs," pp. 43-45.

21 On the debate, see Arif Dirlik and Xudong Zhang (eds.), Postmodernism \& China (Durham: Duke University Press, 2000).

22 Xiaobing Yang, "Answering the question: what is Chinese postmodernism/post-Mao-Dengism?" in Pang-Yuan Chi and David Der-Wei Wang (eds.), Chinese Literature in the Second Half of a Modern Century (Bloomington: Indiana University Press, 2000), p. 201

23 Ibid. p. 212.

24 Wang Ning, "The mapping of Chinese postmodernity," in Dirlik and Zhang, Postmodernism, p. 25.

25 Ibid. p. 30.

26 See Jason McGrath, Postsocialist Modernity (Stanford, CA: Stanford University Press, 2008).

27 Arif Dirlik and Maurice Meisner (eds.), Marxism and the Chinese Experience (Armonk, NY: M.E. Sharpe, 1989), p. 364.

28 Chris Berry, "Getting real: Chinese documentary, Chinese postsocialism," in Zhang Zhen (ed.), The Urban Generation: Chinese Cinema and Society at the Turn of the 21st Century (Durham, NC: Duke University Press, 2007), p. 116.

29 Sheldon H. Lu, Chinese Modernity and Global Biopolitics (Honolulu: University of Hawai'i Press, 2007), p. 208; see also Zhang Xudong, Postsocialism and Cultural Politics (Durham, NC: Duke University Press, 2008), pp. 10 and 13. 
reception of the web-based reality show; and finally the party-state's censorship of webcasting and the netizens' reactions.

\section{The Chinese Reality Show Genre}

This section investigates how the cultural import of European and US reality shows functions in China's mediasphere, exploring the nexus between global and local popular culture in the Chinese reality show genre. The global popularization of digital technology has produced a new kind of localized reality show epitomized by Big Brother. Its original Dutch version first aired in 1999 has engendered international versions and adaptations. ${ }^{30}$ Reality TV or "factual popular television" straddles the borderlines between information and entertainment, and documentary and drama, and includes surveillance reality formats, reality games, life-style and talent shows. ${ }^{31}$ Scholars agree on "reality TV" being a misnomer or oxymoron. ${ }^{32}$ Mark Andrejevic has described Big Brother-style reality TV as a subgenre focusing on the "comprehensive monitoring of unscripted rhythms of life." 33 While Big Brother alludes to George Orwell's (1903-50) dystopian novel Nineteen Eighty-Four (1949) dramatizing omnipresent surveillance, an aspect examined by Andrejevic, ${ }^{34}$ this study focuses on the cultural and commercial aspects of reality show adaptations for the Chinese market, including cynical marketing. The following offers a brief overview of Chinese reality TV adaptations.

The term zhenrenxiu (真人秀, reality show) - coined by Qinghua 清华 University scholar Yin Hong 尹鸿 - first appeared in China with The Great Survival Challenge (Shengcun datiaozhan 生存大挑戰, 2000), a Guangzhou Television show re-enacting the survival on the Long March, and became popularized in 2002 with the broadcast of the Sichuan Television show Into Shangri-la (Zouru xianggelila 走入香格裡拉), an unlicensed adaptation of the US version Survivor (2000). ${ }^{35}$ Zhenrenxiu (literally "real person show") both translates and transliterates the title of The Truman Show (1998, directed by Peter Weir), a Hollywood film about a man whose life is broadcast by hidden cameras without his knowledge. ${ }^{36}$ Yin Hong adapted the term for the Chinese context because it "reveals the essence of reality TV as a commercialized spectacle," ${ }^{37}$ defining it as

30 See Richard Kilborn, Staging the Real (Manchester: Manchester University Press, 2003); Sue Holmes and Deborah Jermyn, Understanding Reality Television (London: Routledge, 2004).

31 Annette Hill, Reality TV: Audiences and Popular Factual Television (London: Routledge, 2005), pp. 7-8.

32 Michael Keane, Anthony Y. H. Fung and Albert Moran, New Television, Globalisation, and the East Asian Cultural Imagination (Hong Kong: Hong Kong University Press, 2007), p. 145.

33 Mark Andrejevic, Reality TV: The Work of Being Watched (Lanham: Rowman \& Littlefield Publishers, 2004), p. 8.

34 Ibid.

35 Michael Keane, "A revolution in television and a Great Leap Forward for innovation? China in the global television format business," in Albert Moran and Michael Keane (eds.), Television across Asia (London: RoutledgeCurzon, 2003), p. 91; Keane et al., New Television, p. 154.

36 Yu Huang, "The Zhenrenxiu phenomenon," p. 3.

37 Ibid. p. 6. 
a documentary-cum-comedy with seven elements ${ }^{38}$ : voluntary participants, audience involvement, competition, rules for elimination and selection, rules for time and space, on-the-spot documentary, and post-production editing. ${ }^{39}$ Yin Hong points out that "contents-wise zhenrenxiu combines zhen 真 in the meaning of zhenshi 真实 (real) and xiu 秀 in the meaning of xugou 虚构 (fictional); its form merges documentary and drama; and its dissemination takes place through both watching and participating." 40 The character xiu also alludes to xuanxiu 选 秀, talent shows with voting mechanisms, such as CCTV's Dream China (Mengxiang Zhongguo 梦想中国) and Super 6+1 (Feichang $6+1$ 非常 $6+1$ ). ${ }^{41}$

For Chinese audiences the appeal of reality shows lies in the combination of indigenous and transnational elements of popular culture, and the play on “real” (zhen 真) and "nonreal” ( jia 假), ${ }^{42}$ a literary tease familiar from traditional Chinese fiction, transposed into the contemporary context of globalizing entertainment culture. ${ }^{43}$ Reality shows, mainly adaptations of successful European or US reality TV formats, had a breakthrough in China in 2005 with the success of Hunan Satellite TV's all-female singing contest Supergirl (Mongolian Cow Yogurth's Supergirl's Voice, Mengniu chaoji nüsheng 蒙牛超級女聲, 2004-), a Chinese adaptation of American Idol (2002) drawing an estimated 400 million viewers. ${ }^{44}$ Chinese reality shows cover the main international reality TV subgenres of Big Brother-style documentaries, American Idol-style elimination game and talent shows, and Extreme Makeover-style self-improvement shows, but also "educational reality shows" such as Dragon Dream (Chenglong jihua 成龙计划, 2006) targeted at middle-school students. ${ }^{45}$

Soul Partners has an antecedent in Hunan Economic Television's Big Brother adaptation Perfect Holiday (Wanmei jiaqi 完美假期, 2001) featuring 13 contestants in a luxury holiday villa facing weekly elimination; the winner received a cash prize of 500,000 yuan. ${ }^{46}$ Similar to Soul Partners, the moderately successful Perfect Holiday sold new consumer dreams - in this case luxury holidays - to its audience.

Reality shows soared in popularity, spurring both licensed and unlicensed spinoffs of successful international formats in addition to indigenous Chinese versions. ${ }^{47}$ They are mainly broadcast on satellite or cable TV, but also appear

38 Yin Hong, “Jiedu dianshi zhenrenxiu” (“Interpreting reality shows”), Jinchuanmei (Today's Media), No. 7 (2005), p. 17.

39 Yin Hong, Lu Hong and Ran Ruxue, "Dianshi zhenrenxiu de jiemu yuansu fenxi" ("Analysing the elements of reality shows"), Xiandai chuanbo (Modern Media), Vol. 136, No. 5 (2005), pp. 47-52.

40 Yin Hong, "Interpreting reality shows," p. 14.

41 Yu Huang, "The Zhenrenxiu phenomenon," p. 6.

42 See Yin Hong, "Interpreting reality shows," p. 16.

43 See, for example, Cao Xueqin, Hongloumeng (Beijing: Renmin wenxue, 1957), Vol. 1, p. 5.

44 Keane et al., New Television, pp. 123-39.

45 See Wang $\mathrm{Xi}$ and Zhang Yuan, “'Jiaoyu zhenrenxiu' jiemu de tansuo yu maodun: yi Tianjin weishi 'Chenglong jihua' jiemu weilie" ("Exploration and contradiction of educational reality shows: a case study of Tianjin Satellite's Dragon Dream," Xinwenjie (Realm of Journalism), Vol. 4. (2006), pp. 72-73.

46 Keane et al., New Television, p. 156.

47 See Keane, "Revolution," pp. 90-91. 
via national CCTV channels, newspapers or the internet. Official estimates in 2007 gave the number of reality shows broadcast on Chinese television stations as 500.48 The State Administration of Radio, Film and Television (Guojia guangbo dianying dianshi zongju 國家廣播電影電視總局, SARFT), the government body responsible for media control, guided reality TV broadcasts through 2005 and 2006, but issued severe restrictions in 2007 and 2008: banning reality TV broadcasts during prime-time $(7.30 \mathrm{pm}-10.30 \mathrm{pm})$; prohibiting voting by mobile phone, telephone or via the internet; controlling their contents; curbing the flamboyance of participants, presenters and performances; and limiting the number and length of reality TV broadcasts. ${ }^{49}$ Perfect Holiday and Chongqing Satellite's acting talent show First Heartbeat (Diyici xindong 第一次心动), for example, fell under the censor's axe. ${ }^{50}$

In 2005 Hunan Television group channel ETV staged a self-improvement reality show entitled Angels Love Beauty (Tianshi ai meili 天使爱美丽) that followed the process of 14 women undergoing plastic surgery. ${ }^{51}$ The show topped the ratings in September 2005 while drawing viewers' complaints about the details of its coverage. ${ }^{52}$ In 2006 Shenzhen Satellite TV station and Shaolin Temple jointly produced the reality show Global Chinese Kungfu Star TV Competition (Zhongguo gongfu zhixing quanqiu dianshi dasai 中国功夫之星全球电视大赛) to select the “Supermonk” (chaoji heshang 超级和尚). The head of Shenzhen Satellite TV expected about 200,000 contestants to register. ${ }^{53}$

In 2006 SARFT turned down Hunan Satellite TV's application for a male version of Supergirls, yet in 2007 Shanghai Dragon TV launched the male singing contest show My Hero! or Happy Boys'Voice (Jiayou haonan'er 加油好男儿). Several restrictions applied, including a veto on combining "super" and "boys" in the title. ${ }^{54}$ In 2006 the business talent show Win in China (Ying zai Zhongguo 赢在中国) appeared on CCTV's economic Channel Two. ${ }^{55}$ The producers adapted the format of The Apprentice from US (2004) and British (2005) versions for the Chinese cultural context by modelling the entrepreneur candidates on the heroes from the Ming dynasty novel The Water Margin

48 Xinhua, "China moves to clean up TV screens," China Daily, 12 January 2007, http://www.chinadaily. cn/china/2007-01/12/content_782593.htm, accessed 3 March 2007.

49 Liu Yanhong, "Zhenrenxiu jiemu de bentuhua jincheng" ("The localization of reality TV"), Shitingjie (Broadcasting Realm), No. 1 (2009), pp. 82-84.

50 Yu Huang, "The Zhenrenxiu phenomenon," p. 7. On Perfect Holiday, see Liu Yuying, "Zhenren zuo xiu" ("Real people make a show"), Xinwen zhoukan (News Weekly), No. 37 (2002), pp. 43-45.

51 Cheng Xiaoxuan, "Nüxing xingxiang: ziwo chengxian yu meijie chengxian" ("The woman phenomenon: self-presentation and media-presentation"), Xinwen zhishi (Journalism Knowledge), No. 2 (2009), pp. 58-60.

52 See Roland Soong, "Bloody television," EastSouthWestNorth, http://www.zonaeuropa.com/200509 brief.htm, accessed 20 September 2009.

53 "Shaolin facaijing" ("Shaolin temple commercialized"), Epoch Times, 15 April 2006, http://www. epochtimes.com/gb/6/4/15/n1287881.htm, accessed 21 October 2009.

54 See Yin Hong and Yan Qingsheng, "Chuangxin yule" ("Innovative entertainment"), Zhongguo guangbo dianshi xuekan (Chinese Media Journal), No. 10 (2006), pp. 39-40.

55 Bai Yanyan, "Zhenrenxiu Ying zai Zhongguo jiemu yuansu fenxi" ("Analysing the reality show Win in China”), Dongnan chuanbo (Southeast Media), Vol. 42, No. 2 (2008), pp. 1-2. 
(Shuihu zhuan 水潡傳). Mirroring the number of outlaws in the novel, 108 participants selected from 120,000 online applicants competed for a business prize worth ten million yuan. ${ }^{56}$ Beijing Satellite TV aired the talent show People in the Dream of the Red Chamber (Hongloumeng zhong ren 红楼梦中人) inspired by the Qing dynasty novel. The subgenre of talent shows with traditional Chinese characteristics shows how indigenous, traditional and globalizing elements of popular culture merge in the reality genre import.

The "strangers in a room" genre engendered new variants in 2007 alongside Soul Partners. First, the UK reality show Wife Swap (2003) inspired two similar programmes in China: Wife Swap (Jiaohuan zhufu 交换主妇) by Qilu TV Shandong, exchanging spouses between city and countryside, and Life Swap (Bianxingji 变形记) by Hunan Satellite TV exchanging other family members; in its first episode teenage boys from a wealthy urban family and an impoverished rural household swapped places. ${ }^{57}$ The storyline detailing the moral reform of the spoilt urban boy, a school dropout and internet addict, through his "education" in the countryside, shares themes with fiction about model communist heroes, ironically echoing elements from socialist realism drama in the quest for "real stories."

A Big Brother-style reality show with real monkeys received coverage in national newspapers when six contestants entered a monkey cage in Qinling 秦 岭 Zoo, Shaanxi 陕西, to live with the animals for four days. The prize for the survivor - the last person to leave the cage - included 11,888 yuan and the conferment of the honorary title "animal lover." 58

Despite SARFT's restrictions, Sichuan Cable TV launched China's Next Top Model (Panting shanliang mofang 潘婷闪亮模坊; later Meili mofang 美丽模坊) in 2008, an adaptation of America's Next Top Model. ${ }^{59}$ New reality shows launched before the Beijing Olympics predominantly featured sports, such as Shanghai TV station Eastern Satellite's Skating with Celebrities (Mingxing da lianbing 明星大练冰) and Zhejiang TV's talent show True Boys Dreaming of Olympics (Hao nan'er mengxiang aoyun 好男儿梦想奥运). ${ }^{60}$ Bloggers and scholars began to predict the demise of talent shows on Chinese television as a result of censorship. ${ }^{61}$

56 Michael Keane, Created in China (London: Routledge, 2007), p. 124.

57 See Xi Liu, 'Bianliang de shiyan haishi yanyi de xiuchang: cong 'Bianxingji' yu 'Wife Swap' de duibi kan zhenrenxiu dianshi jiemu" ("Experience of the variable or showground of deduction: comparing Life Swap and Wife Swap for a study of reality TV"), Kejiao wenhui (Science Education Journal), No. 5 (2008), p. 165.

58 "Big Brother the Chinese way with real monkeys," Telegraph, 9 February 2007, http://www.telegraph. co.uk/news/main.jhtml?xml=/news/2007/02/09/wmonk09.xml, accessed 11 February 2007.

$59 \mathrm{Hu}$ Wenwen, "Meili mofang: xuanxiu jiemu xinfengshang" ("China's Next Top Model: new trends in talent shows”), Guanggao daguan (Advertising Survey), No. 5 (2009), pp. 119-20.

60 CMM-I, Zhongguo meiti nianjian: 2008 China Media Yearbook \& Directory (Beijing: CMM-I, 2008).

61 Wang Xiaofeng, "Xuanxiu de zhongjie: quanmin yule yundong shiheng" ("The demise of talent shows: imbalances in mass entertainment"), Sanlian shenghuo zhoukan (Sanlian Life Weekly), No. 34 (2007), pp. 36-38; Yu Huang, "The Zhenrenxiu phenomenon,” p. 17. 


\section{Soul Partners and the Quest for Authenticity}

This section explores how Soul Partners as a Chinese adaptation of foreign reality formats negotiates the quest for authenticity in post-socialist discourse. Following Michel Foucault's proposal to understand the concept of authenticity through the "analysis of the 'games of truth' ... through which being is historically constituted as experience,"62 Prasenjit Duara identifies "the order of authenticity" in Chinese representational practices in politics and culture "to identify [national] essences and search for roots" and also in Rey Chow's "primitive passions" represented in Chinese cinema. ${ }^{63}$ This study defines the quest for authenticity as the search for representing "truth" or the "real" (zhen) in China's post-socialist discourse as opposed to the staged spectacles of socialism and the representation of prescribed character in socialist realism. ${ }^{64}$

Soul Partners uses webcasting to move the quest for authenticity into the PRC's cybersphere. It belongs among a new wave of web-based reality shows exposing private lives and commercial culture while feeding on what Lyotard has called our "pornographic appetite for the real."65 A Taiwanese web-based reality show Real Life Photography Studio (Shenghuo yingxiang guan 生活影像 馆) allowed viewers, for a charge, to survey a group of young people round the clock everywhere inside their home, provoking controversy in mainland Chinese media in 2002. 66 Teflon used a web-based reality show in 2006 to advertise its cookery products in China. ${ }^{67}$ Soul Partners features six protagonists in their early 20s selected online as in Into Shangri-la: the male participants are Zhang Libin 张黎斌, Yuan Xiaoyi 袁晓毅 and Cheng Xi 程曦; the females are Ma Ding 马丁, You Zhixin 有之欣 and Tang Duo 汤朵. All are students except media freelancer Tang Duo. Their only prompt is to "play themselves." 68 Soul Partners stipulates that no talent or training is required other than "the courage to show one's authentic side (zhenshi 真實)" and spare time at weekends for the shooting. ${ }^{69}$ The show promises to turn ordinary Chinese citizens into celebrities.

In accordance with the demands of the reality TV genre, the Soul Partners website claims that there is "no script." The participants instead "enact urban modernity freely," pursuing the profane activities of daily life. ${ }^{70}$ The website emphasizes that they can discuss any topic freely and develop their show without

62 Michel Foucault, The History of Sexuality, Vol. 2, The Use of Pleasure (London: Viking, 1986), pp. 6-7.

63 Prasenjit Duara, "The regime of authenticity: timelessness, gender, and national history in modern China," History and Theory, Vol. 37, No. 3 (1998), pp. 287-308, esp. p. 295; Rey Chow, Primitive Passions (New York: Columbia University Press, 1995), pp. 21-23.

64 On authenticity in Chinese reality TV, see Keane et al., New Television, pp. 72, 141-57.

65 Terry Eagleton, "Forgive me, Big Brother, I have sinned," The Sunday Times, 8 June 2008, sec. 5, p. 3.

66 Anon., "Wangluo zhenrenxiu: Women hai you mimi ma?" ("Web-based reality shows: do we still have secrets?”), Jisuanji jiaoyu xue (Computer Pedagogy), No. 1 (2002), p. 73.

67 Shang Silin, "Tefulong "zhudong chuji"” ("Teflon attacks first in cooking"), Shangwu zhoukan (Business Weekly), No. 8 (2007), pp. 78-79.

68 Soul Partners, http://actor.mofile.com/index/htm, accessed 2 June 2007.

69 Soul Partners, "Zhaomu guize" ("Rule"), http://actor.mofile.com/index/rule.do, accessed 4 May 2007.

70 Soul Partners, "Huodong xiangqing" ("Detail"), http://actor.mofile.com/index/detail.do, accessed 5 May 2007. 
any restrictions. This claim appears to defy the party-state's control of cultural production and consumption, redefining China's cultural parameters where state censorship and self-censorship limit freedom of expression. Soul Partners' reliance on storyline and plot, however, turn the reality show into pastiche. The plot traces the adventures of six young people with the spending power to purchase a luxury apartment in Thames Town. A greedy developer has tricked each of them into buying the same flat and issued them with identical keys and a copy of the same contract. The participants only discover the fraud when each of them moves in. As nobody is willing to give up their property, they stay on to fight but turn into friends. The programme traces their social interactions within their new home. The "reality show" thus turns out to be carefully constructed.

While Soul Partners adapts some elements from the Big Brother format specifically the "strangers in a room" situation and the idea of documenting the daily lives of participants disconnected from all familiar social ties - the audience does not vote the participants off. The show stages rather than tracks the participants' movements as in the television drama format. Mofile claims that Soul Partners gives authorial powers to its audience, in accordance with the Big Brother producers' insistence on audience interaction as a required element of reality TV. ${ }^{71}$ Director Zheng Kai 鄭凱 (1981-) from Wuhan, an award-winning Beijing Broadcasting Institute 北京廣播學院 graduate (2004) and Shanghai resident, announces that the viewers' feedback helps develop the show: "We are always communicating with our internet audience and adjusting our episodes accordingly. We have always been adjusting our look, our structure and our content according to their feedback, but also by keeping in line with the principles of making television." 72

True to the spirit of reality TV, Soul Partners producers claim to collapse the distance between producers and consumers by portraying the viewers as taking part in the process of production, ${ }^{73}$ yet this feature implicitly spoils the illusion that the show provides access to "reality" as it happens. The ensuing adventures of the participants within their enclosed home revolve around their conversations, tears and laughter in the living room, kitchen, bedroom and bathroom, teasing the audience with the potential for risqué behaviour. The show reinforces such "candid camera"-style expectations, showing one male participant cursing on the lavatory.

The US show Candid Camera, first aired in 1948, constitutes the prototype of the reality TV format. ${ }^{74}$ The concept of the candid camera also features in recent Chinese avant-garde video art, constructing new urban spaces that transcend the

71 Andrejevic, Reality, p. 12.

72 ITN, "Viewers call shots on China show," 3 March 2007, http://itn.co.uk/news/db78f9dde38f3bc62d 329617322a25be.html, accessed 7 April 2007.

73 Andrejevic, Reality, p. 9.

74 Bradley Clissold, "Candid Camera and the origins of reality TV," in Holmes and Jermyn, Understanding, p. 33. 
public/private boundaries as Sheldon Lu has shown. ${ }^{75}$ Video artist Cui Xiuwen 崔岫闻 (1970-) used a secret camera to film prostitutes in the ladies' lavatory at a Beijing nightclub. ${ }^{76}$ Her six-minute reality video Ladies' (Xishoujian 洗手 间, 2000) exposes the women's private moments in front of the bathroom mirror. Yet the vision of their authentic "selves" ultimately appears as an illusion, artistically enhanced by the camera's focus on the mirror, implying that the "real" women never appear in the spectator's gaze. Soul Partners too leads the spectator into the lavatory but replaces sexual titillation with burlesque comedy. Popular culture and avant-garde converge in the experiment with discovering and documenting "reality," staging the exposure of authenticity as a post-socialist spectacle.

Michael Keane has shown that Chinese reality TV draws on three traditions: socialist realism, socialist "mock" documentary and myths of collective struggle. ${ }^{77}$ Socialist realism or "representational realism" (xianshi zhuyi 现实主 义), as Chris Berry notes, has come "to carry a connotation of fakery or at best reality as the authorities wish it were." 78 Soul Partners, by contrast, claims to share with the reality TV format the use of "on-the-spot realism" (jishi zhuyi 及时主义). This new kind of realism is associated with the new documentary makers of the 1990s who have been trained in television-making institutions and predominantly use video. ${ }^{79}$ The play on reality and illusion that reality shows such as Soul Partners epitomize has also exercised the Urban or Sixth Generation filmmakers such as Lou Ye 娄烨 (1965-) whose "dreamy documentary" of Shanghai Suzhou River (Suzhou he 苏州河, 2000) dramatizes the blurring of the borderline between reality and fiction. ${ }^{80}$

Chris Berry notes that this new mode of filmmaking belongs to the era of postsocialism, originating in the desire to "get real," in the dual meaning of representing the "real" and awakening from illusion. ${ }^{81}$ The docu-soap subgenre of Chinese reality shows such as Soul Partners resembles the new documentaries Bumming in Beijing: The Last Dreamers (Liulang Beijing - Zuihou de mengxiangzhe 流浪北京 最后的梦想者, 1990) ${ }^{82}$ and I Graduated! (Wo biyele 我毕业了, 1992) in the drive to stage unscripted spontaneity, the use of a handheld camera with its technical lapses, and the reality show staple of spontaneous tears reproducing the raw quality of documented "reality." ${ }^{3}$ Originating in the French cinéma vérité, the trend of "getting real" also shares some characteristics with Urban or Sixth Generation filmmakers such as Jia Zhangke 贾樟柯 (1970-), specifically the use of amateur

75 See Lu, Modernity, p. 185-86.

76 "Cui Xiuwen zuopin 'Xishoujian',” blog sina, http://blog.sina.com.cn/s/blog_47633a370100f3qf.html, accessed 16 October 2009.

77 Keane, "Revolution," p. 101.

78 Berry, "Getting real," p. 123.

79 Ibid. pp. $122 \mathrm{ff}$.

80 Zhang Zhen, Urban Generation, p. 363.

81 Berry, "Getting real," pp. 115-16.

82 The Soul Partners website also describes the show as a "reality soap comedy" (zhenren feizao xiju).

83 Berry, "Getting real," pp. 117-22. 
actors, low-budget productions, documentary-style drama and the focus on the ordinary and mundane. ${ }^{84}$ In Soul Partners the amateur actors enact the docudrama of the diurnal rhythm of life. The show's setting within the dreamscape of ultramodern luxury developments, however, turns the drive to get real into pastiche.

Soul Partners incorporates elements from television drama (dianshi ju 电视剧) and soap opera (feizao ju 肥㿝剧), including the reliance on plot, indoor drama and comedy. Television drama began in China in 1958, concurrent with the advent of television as a new media technology in China. ${ }^{85}$ It proliferated in the 1990s in a variety of subgenres, including serial (lianxu ju 连续剧), comedy (xiju 喜剧), indoor drama (shinei ju 室内居) and soap opera. As an indoor drama Soul Partners draws on the 1990 television programme Yearnings (Kewang 渴望), the first multi-episode in-room serial in China shot in a studio and sponsored by non-state sources. ${ }^{86}$ Di Miao has examined Beijing film director Ying Da's 英达 (1960-) Western-style sitcoms and television programmes including Chinese Restaurant (Zhongguo canguan 中国餐馆, 1998) and I Love My Family (Wo ai wo jia 我爱我家, 1993) ${ }^{87}$ As with Soul Partners, Ying Da's works - showing young people living together - on the surface appear to lend themselves to interpretation as Chinese versions of the US sitcom Friends (1994-2004). Yet the following section argues that the Chinese reality show reveals more about the new trends and dreams in Chinese cultural discourse if analysed within its local contexts.

\section{New Dreams for a New Generation}

This section traces the formation of new dreams and aspirations for a new generation as portrayed in Soul Partners by examining character and setting. I investigate how Soul Partners dramatizes the dreams of getting rich and famous, generating new aspirations in post-socialist China. Zhang Xudong says that postsocialism describes the "emergence of a Chinese everyday world and mass culture" reactive to Mao's China. ${ }^{88}$ Here I use the concept to position China's post-Mao generation and their new dreams within their changing world.

Terry Eagleton notes the banality underlying the postmodern architecture of Big Brother-style reality shows: "In a postmodern age, plot, storyline, action and language have all become redundant. Only one thing remains ... and that is character." 89 Soul Partners differs by not dispensing with plot altogether,

84 On Jia Zhangke, see Lu, Modernity, pp. 152-55.

85 Yin Hong, "Meaning, production, consumption: the history and reality of television drama in China," in Stephanie Hemelryk Donald, Michael Keane and Yin Hong (eds.), Media in China (London: Routledge, 2002), p. 30.

86 Ibid. p. 32.

87 Di Miao, "A brief history of Chinese situation comedy," in Ying Zhu, Michael Keane and Ruoyun Bai (eds.), TV Drama in China (Hong Kong: Hong Kong University Press, 2008), pp. 117-28.

88 Zhang Xudong, Postsocialism, p. 15.

89 Eagleton, "Forgive," p. 3. 
but shares the emphasis on character. Character in Soul Partners appears in three forms: the participants, creators and audience. This section focuses on their common denominator: perceived membership of a new generation.

Like the participants, the creators of Soul Partners - producer Xun Xiang 菖香 (1985-) from Kunming, directors Zheng Kai and Han Tianxing 韩天馨 (1982-) from Shanghai 90 - belong to the "brand-new human race" (xin xin renlei 新新人 類) born in the late 1970s and 1980s, "Generation X," or in cultural scholar Jing Wang's phrase, urban "neo-neo-tribes."91 They have no memories of Mao's China, grew up during the reform era and came of age when post-socialism, transnational capital and consumerism transformed the nation. ${ }^{92}$ Jing Wang characterizes this new group of consumers as "hub influentials," an urban population with globalized tastes, and identifies a subgroup of "bourgeois bohemians" (bobo 波波, bubo 布波) driven by creative aspirations and interests in success and wealth - a label gaining currency in China since 2002.93 Advertisers fuelled a "bobo marketing craze" in Chinese cities, targeting the Generation X's desire for a luxury life-style.

The concept of reality show participants as unscripted characters who represent "unscripted modernity" contrasts with the socialist heroes that dominated Mao and post-Mao China in the staged spectacles of the grand socialist master narrative. ${ }^{94}$ As Yin Hong notes, the success of reality formats in China rests on Chinese audiences having tired of "socialist mainstream melody" (shehuizhuyi zhuxuanlü 社会主义主旋律) programmes rehashing the officially sanctioned versions of popular entertainment and dominating prime-time CCTV. ${ }^{95}$ While international reality TV thrives on the promise of replacing escapist entertainment with the "authentic,"96 Chinese reality shows appear to replace the socialist grand narrative with the "small stories" of "real" people. ${ }^{97}$ The protagonists appear to replace not only Mao's socialist heroes - model workers, peasants and soldiers - but also the anti-heroes of post-Mao fiction such as Wang Shuo's hooligans with post-socialist constructions of "authentic people." Paradoxically the concept of authenticity in character is predicated on celebrity culture $^{98}$ : Soul Partners promises to bring fame to the "ordinary" participants, ${ }^{99}$ dramatizing a new dream in post-socialist consumer society.

90 Han Tianxing and Xun Xiang are also Beijing Broadcasting Institute graduates.

91 Jing Wang, Brand New China, pp. 19-20, 180-210.

92 Lu, Modernity, p. 53.

93 Jing Wang, Brand New China, p. 142

94 Reality TV's unscripted characters are "subtly scripted" through "pre-selection of stereotypes." Keane et al., New Television, p. 72.

95 Yin Hong, "Meaning," p. 33.

96 Andrejevic, Reality, pp. 3 and 14.

97 See the discussion of Lyotard in Sheldon Lu, China, Transnational Visuality, Global Postmodernity (Stanford, CA: Stanford University Press, 2001), p. 65.

98 Louise Edwards and Elaine Jeffreys (eds.), Celebrity in China (Hong Kong: Hong Kong University Press, 2009).

99 Soul Partners website. 
By participating in the reality show, the Soul Partners participants enact the dream of getting rich and famous - a dream reactive to Mao discourse but in line with Deng ideology, revealing traces of "residual socialism." The Soul Partners website professes to recruit new participants as "stars," profiling the current participants' height, weight, zodiac signs, abilities and hobbies as if presenting celebrities to their fan club. ${ }^{100}$ While the archetypal Big Brother-style reality show casts the participants as "being themselves," Soul Partners' amateur actors "play" protagonists modelled on themselves. Zhang Libin explains: "In the show I play a young character, but I'm also independent and don't need to rely on my parents." 101 He portrays his character as "cool on the outside but emotional on the inside - not unlike me in real life." 102 The website thus functions as a metanarrative enhancing the illusion of the characters' authenticity in a move away from the protagonists of socialist realism works.

On the Soul Partners website the implied creators of the show also become participants in the spectacle dramatizing "urban reality," as their self-introduction shows:

We are ordinary office workers, working nine to five and leading an ordinary life in Shanghai. One day we saw a glimmer of our dream, ... packed our bags ... and took the streetcar towards our dream ... until we reached our final destination of happiness. ... All those of you who still have a dream, let's set out for the sake of this dream!103

The narrative voice projects the creators' image as ordinary and hence real, mirroring both the participants and the audience as the implied real urban inhabitants whose mundane reality can turn into the dream of happiness (xingfu 幸 福). The narrative voice addresses the implied Generation X audience to emphasize that they too can achieve the dream. The contextual commercial discourse prescribes a formula for "happiness" as Jing Wang has noted: a Guangzhou property company used web-based advertisements in 2003 to market the "happy lifestyle of bobos" to prospective Generation X customers, defining "happiness” as combining freedom (ziyou 自由), wealth (caifu 財富) and thoughtfulness (jingguo sikao 經過思考), ${ }^{104}$ thus spelling out the new aspirations as advocated by the advertising industry.

As consumers, China's Generation X profess to internalize the apolitical discourse that the Party has promoted since Deng Xiaoping's Southern Tour in 1992. They have created an urban youth culture embracing the chic of "alternative (linglei 另類) cool" embracing fashion, electronics and computer games, ${ }^{105}$ items that also preoccupy the Soul Partners participants. China's Generation X derive their name from their Japanese counterparts (shinshin jinrui 新新人類). Jing Wang describes Japan's neo-neo-tribes as a generation with weak family

100 Ibid.

101 Taylor, "Chinese Friends."

102 Ibid.

103 Soul Partners website.

104 See Jing Wang, Brand New China, pp. 185-86.

105 Ibid. pp. 228ff. 
ties tending "to prefer friendship over family bonds."106 Soul Partners grotesquely heightens this aspect, portraying friendship as the only social bond in the participants' world. The linglei discourse has its roots in Wang Shuo's hooligan (liumang 流讯) culture of the 1980s. While Wang Shuo mocks the Chinese Communist Party discourse, Soul Partners - similar to the linglei writers appears to have internalized the Party line about consumption, but in the process begins to imagine a world with the new social and moral "freedoms" that wealth appears to entail.

The setting in Soul Partners dramatizes another dream in post-socialist Chinese discourse: home-ownership. ${ }^{107}$ The participants play protagonists rich enough to buy a luxury flat in the newly constructed Thames Town in Songjiang 宋江 district, a residential development cloning an English market town. ${ }^{108}$ In 1991 the Chinese government made Shanghai the test-bed for its housing commodification reform plan and in 2001 launched gigantic urbanization projects in Shanghai's suburban orbit, designing a scheme of nine themed satellite towns including Thames Town. The Soul Partners "150 square metre luxury apartment" - originally purchased for one single occupant - relegates Mao-era living conditions to oblivion. ${ }^{109}$ In 1949 Shanghai residents occupied an average 3.7 square metres per person, which had reduced to only 2.2 square metres by $1963 .{ }^{110}$ The national urban average approximated 3 square metres per person in 1976, rising to 7.5 square metres in 1993. ${ }^{111}$ Official PRC sources set it at 28 square metres in 2008. ${ }^{112}$ Although lower than other cities, Shanghai per capita floor space also rose dramatically from 12.5 square metres in 2001 to 16 square metres in 2006. ${ }^{113}$ These figures make the Soul Partners setting appear extravagant.

In 2005 Thames Town residences built for 10,000 "young wealthy consumers" ranged from US\$490,000 for a three-bedroom villa to US\$669,000 for more spacious houses. ${ }^{114}$ White-collar workers account for 100 million consumers or 8 per cent of China's total population but felt strapped for cash when home-ownership

106 Ibid. p. 203.

107 Lu, Modernity, p. 169.

108 Jade Franklin, "The art of imitation: Thames Town and the copy in China," Dameishu (Fine Arts), No. 6 (2007), pp. 153-56.

109 David Fraser, "Inventing oasis: luxury housing advertisements and reconfiguring domestic space in Shanghai," in Deborah S. Davis, The Consumer Revolution in Urban China (Berkeley: University of California Press, 2000) p. 30.

110 Chen Xiangming and Gao Xiaoyuan, "Urban economic reform and public housing investment in China," Urban Affairs Quarterly, Vol. 29, No. 1 (1993), p. 120.

111 Ya Ping Wang and Alan Murie, "The process of commercialisation of urban housing in China," Urban Studies, Vol. 33, No. 6 (1996), pp. 973, 980, 987.

112 National Bureau of Statistics, China Statistics 2005, 26 April 2006, http://www.allcountries.org/ china_statistics/10_1_people_s_life.html, accessed 8 August 2009.

113 Shanghaishi tongjiju (Shanghai Statistics Bureau), "2006 nian Shanghaishi guomin jingji he shehui fazhan tongji gongbao" ("Statistical report of Shanghai citizens' economic and social developments in 2006”), 7 February 2007, http://210.72.32.6/cgi-bin/bigate.cgi/b/g/g/http@www.stats.gov.cn/tjgb/ ndtjgb/dfndtjgb/t20070420_402400624.htm, accessed 8 August 2009.

114 Hannah Beech, "Ye olde Shanghai time," Time, 7 February 2005, http://www.time.com/time/printout/ 0,8816,1025219,00.html, accessed 2 August 2009. 
expenses soared in 2005. ${ }^{115}$ Gold-collar workers (jinling 金領) can afford luxury goods but only make up an estimated one million customers nationwide. ${ }^{116}$ Thames Town epitomizes consumer dreams out of reach for most Chinese citizens. The commercial discourse reinforces this aspect: Shanghai developer Henghe 恒和 Real Estate Company Ltd markets Thames Town as a fairy-tale backdrop for the reality show Happy Boys' Voice. ${ }^{117}$

The new advertising industry - reborn from the ashes of Mao's China in 1979 fosters the dream of the ideal home that Soul Partners projects. King and Kusno have shown how the Chinese cultural discourse constructs apartment buildings as "metaphors of modernity." 118 The view from the windows reveals the Soul Partners apartment as part of an ultra-modern dreamscape of luxury apartment buildings interspersed with gardens, woods and a shopping mall. David Fraser has shown that Shanghai's new estate agents peddle the dream of owning an “urban oasis” (lüzhou 綠洲), constructing “alternative realities” in their advertising discourse. ${ }^{119}$ The Thames Town developers echo the dream of the urban oasis as the new ideal place of residence on their website. ${ }^{120}$

Soul Partners' setting features a furnished apartment resembling the Ikea showrooms that opened in Shanghai in 1998. In a study of 21 st-century Shanghai homeowners, Deborah Davis notes that "Ikea promotes a vision of an ideal ultra-modern home interior" suitable for middle-income budgets in China. ${ }^{121}$ In 2004 the Shanghai Ikea franchise advertised a model room for an unmarried couple under the slogan "moving in together." 122 Mofile director Andy Fan acknowledges that Soul Partners reflects new social trends and moral attitudes: "Maybe five years ago, for males to share the same apartment with females would have been unacceptable." 123 This scenario may not yet have become the status quo in contemporary China, but it resonates with the linglei literary discourse. ${ }^{124}$

Soul Partners, in sum, constructs a hyper-real version of post-socialist modernity: individual fame, wealth, commodity housing and consumer dreams merge in the construction of a new spectacle. This vision differs from China's homebuyers' more common realities: a new apartment usually means an unfinished shell without interior equipment requiring further investment. ${ }^{125}$ Soul Partners maps the virtual dreamscape of metropolitan hyper-modernity as a designer

115 Jing Wang, Brand New China, p. 11.

116 Ibid. p. 12

117 Thames Town website, http://www.thamestown.com/culture3_2.htm, accessed 10 October 2009.

118 On apartment buildings as metaphors of modernity, see Anthony D. King and Abidin Kusno, "On Be (ij)ing in the world: 'postmodernism,' 'globalization,' and the making of transnational space in China," in Dirlik and Zhang, Postmodernism, pp. 50-55.

119 Fraser, "Oasis," p. 29.

120 Thames Town website.

121 See Deborah Davis, "Urban consumer culture," The China Quarterly, No. 183 (2005), p. 703.

122 Ibid.

123 Taylor, "Chinese Friends."

124 See e.g. Wei Hui, Shanghai baobei (Shanghai Baby) (Hong Kong: Tiandi tushu, 2000), p. 1.6.

125 Davis, "Urban consumer culture," p. 699. 
city based on Western models. Part theme-park, part consumer dream, the globalized city within the heart of China symbolizes post-socialist ultra-modernity. In a twist on Shanghai's colonial past, the Western world has come home in the postcolonial site of 21st-century Shanghai, becoming internalized in the Chinese market as an indigenous product.

\section{Reception}

Mofile claims the show received 2.8 million hits from netizens from the PRC and Greater China. ${ }^{126}$ These statistics belong to the producers' discourse for public consumption: the hit score features prominently on the Mofile website. Whether this represents a true reflection of the audience, however, is uncertain. A manipulation of the score would work in the producers and sponsors' interests: a higher score would enhance the website profile and attract higher advertising revenue while evidence of an international audience would tap into the Thames Town developers' extended target market.

By webcasting, Soul Partners targets China's netizens as its primary audience. According to CNNIC (China Internet Network Information Centre) survey reports, China's web population has become the world's largest with 420 million in July 2010 and a penetration rate of 31.8 per cent. ${ }^{127}$ Just over half of all netizens are male but the gender gap is closing, with the proportion of females rising from 45.1 per cent in 2007 to 47.5 per cent in 2008 but falling again to 45.2 per cent in 2010. ${ }^{128}$ Around half of all netizens are aged under 25, and in 2007 around 80 per cent were under 35 (born in or after 1973). Students account for the largest proportion, 30 per cent or 76 million in 2008. The internet penetration rate is highest for students in tertiary education with 97.5 per cent in 2007. Over three-quarters of netizens live in cities, the majority in east China. In sum, the CNNIC data suggest that the average Soul Partners viewer in 2007 and 2008 typically represents the Generation $\mathrm{X}$ urban educated youth living in the eastern coastal region - Thames Town developers' target consumers. China's netizens regard online video as an increasingly important method of entertainment, with 180 million users in 2008. ${ }^{129}$ The majority of netizens - regardless of gender, age and educational background - trust the internet and consider it as the most important channel to obtain information. ${ }^{130}$ Webcasting thus appears as an effective tool for advertisers.

The netizens' comments debate Soul Partners' merits. Opinions are divided. Some praise it: "I've watched it. What a luxurious setting, I also want to participate ..." (16 January 2007); "Superb! I want to take part in it!" (21 January

126 Mofile website, http://tv.mofile.com/user/soulpartners, accessed 7 September 2008.

127 CNNIC Survey Report (CSR), No. 26 (July 2010); http://research.cnnic.cn/html/1279171593d2348. html, accessed 7 January 2011.

128 CSR, Nos. 20, 25, 26.

129 CSR, No. 22

130 CSR, No. 19 
2007). Other comments voice criticism: “The acting is a bit fake (jia 假), don't you think? But it's not bad." (23 January 2007); "It's a bit fake. Try harder, I'll support you!!" (17 February 2007). ${ }^{131}$ While the viewers appear savvy enough to "see through" the artificiality of the show, their reflections reveal their desire for authenticity. In debating the authenticity of the show, they also consume the commercial message without dismantling the rhetoric of the advertising discourse.

\section{State Censorship of Webcasting and the Netizens' Reactions}

In 2007 SARFT issued severe restrictions on reality TV and webcasting, tightening guidelines for programme design, censoring programmes before broadcasting and monitoring them during transmission, as noted above. But what reactions has the state censorship provoked among the audience? This section looks to the blogosphere for evidence.

Official news agency Xinhua quoted SARFT general director Wang Taihua's 王太華 announcement on 12 January 2007:

There have been too many reality shows on our TV screens. Many are low-quality, low-brow programmes, only catering to the bottom end of the market. The government must strengthen supervision of entertainment programmes, and restrict the number of reality show programmes to upgrade their quality. ${ }^{132}$

SARFT issued regulations to control internet video clips in 2006, requiring registration before they can be published on the internet. ${ }^{133}$ Video-sharing websites Tudou and 56.com suffered temporary shutdowns in 2008, ostensibly for failing to comply with SARFT regulations. ${ }^{134}$

China's netizens perceive SARFT as sending out confusing signals. One SARFT report describes competition-based reality shows as "a new force in the mainland's culture industry," praising their business potential as one of the fastest growing sectors in advertising revenue. ${ }^{135}$ The perceived lack of consensus has provoked ridicule in the blogosphere. Journalist Wang Xiaofeng 王小峰 satirizes SARFT as the "General Administration of Anxiety about Radio, Film and Television” (Guangdian zongji 廣電總急):

Today they get so anxious that they do not permit the filming of legal cases; tomorrow they get so anxious that they do not permit the shooting of historical costume dramas; the day after tomorrow they get so anxious that they do not permit the broadcasting of foreign cartoons.... Recently they wanted to issue another regulation forbidding the webcasting of any video content without a permit. ... According to the organizational setup and scope of the PRC

131 Comments dated 16-21 January 2007; http://tv.mofile.com/ECKNU7E8/1, accessed 22 May 2007 (no longer accessible as of 2008).

132 Xinhua, "China moves to clean up TV screens."

133 Jeremy Goldkorn, "SARFT attacks internet video," 15 August 2006, http://www.danwei.org/ danwei_noon_report/danwei_noon_8_12.php, accessed 3 October 2009.

134 Kaiser Kuo, "56.com incurs wrath of SARFT?" 4 June 2008, http://digitalwatch.ogilvy.com.cn/en/? $\mathrm{p}=268$, accessed 20 September 2009.

135 Peter Feuilherade, "China threatens reality TV crackdown," 16 January 2007, http://news.bbc.co.uk/1/ hi/world/asia-pacific/6263285.stm, accessed 4 May 2007. 
administration, the General Administration of Anxiety about Radio, Film and Television should regulate radio, film and television; the internet should be regulated by the Ministry for Information Industry (Xinxi chanyebu 信息產業部). ... But it is not so straightforward with the internet: everybody seems to have the right to regulate it. It's such a fat piece of meat - who wouldn't want to gobble it up? ${ }^{136}$

This blog mocking the censors' perceived commercial interests demonstrates the cost that the government pays for internet censorship. ${ }^{137}$ This example also illustrates how the cultural, commercial and political discourses merge in China's mediasphere.

\section{Concluding Remarks}

The social, economic and cultural developments of the post-Deng era have changed not only the Chinese cityscape but also the moral map and landscape of the mind in the urban citizen's imagination. Soul Partners dramatizes the development of the new post-socialist culture which is profoundly politically ambivalent and also deeply enmeshed with consumerist values. Analysis of Soul Partners provides new insights into the dynamics of transcultural appropriation in China's mediasphere and the socio-political implications by tracing, first, how global culture affects local discourses; second, how Web 2.0 technology provides a new vehicle for a new cultural discourse; and third, how the cultural and commercial discourses generate new dreams reflecting how 21st-century Chinese citizens perceive the transformation of urban life and how they imagine their future. While internalizing the Party line on apolitical discourse, Soul Partners does not advocate political subversion; yet as an adaptation of globalized entertainment formats and a media spectacle about a new social experiment, it appears on the brink of envisaging a brave new world that relegates the socialist past into oblivion.

This study opens up important avenues for future research on China's popular culture and cultural imagination in the fields of cultural studies, internet studies, media and literary studies. Future work will lead to further exploration of authenticity and performativity in China's mediasphere; the transformation of individual identity; the subversiveness of popular culture; and the ramifications of the "reality trend" in other cultural discourses - from blogs to print and web literature. The focus on such issues will provide new perspectives on China's mediasphere and popular culture.

136 Wang Xiaofeng, "Guangdian zongji” ("The General Administration of Anxiety about Radio, Film and Television”), 15 August 2006, http://www.wangxiaofeng.net/?p=319, accessed 20 June 2007.

137 Yongnian Zheng, Technological Empowerment. 